\section{Physicochemical Properties of Root Canal Filling Materials for Primary Teeth}

Raquel Assed Bezerra Segato ${ }^{1}$, Carolina Maschietto Pucinelli ${ }^{1}$ Danielly Cunha Araújo Ferreira ${ }^{1}$, Andiara De Rossi Daldegan ${ }^{1}$, Roberto S. da Silva², Paulo Nelson-Filho ${ }^{1}$, Léa A. B. da Silva ${ }^{1}$
'Department of Pediatric Dentistry, School of Dentistry of Ribeirão Preto, USP - University of São Paulo, Ribeirão Preto, SP, Brazil ${ }^{2}$ Department of Physics and Chemistry, School of Pharmaceutical Sciences of Ribeirão Preto, USP - University of São Paulo, Ribeirão Preto, SP, Brazil

Profa. Dra. Raquel Assed Bezerra Segato, Avenida do Café S/N, 14040-904 Ribeirão Preto, SP, Brasil. Tel: +55-16-3315-3995. e-mail: raquel@forp.usp.br

\begin{abstract}
This study evaluated physiochemical proprieties of a calcium hydroxide-based paste (Calen ${ }^{\circledR}$ ) combined with a zinc oxide cement at different ratios (1:0.5, 1:0.65, 1:0.8 and 1:1). Materials were compared regarding setting time, $\mathrm{pH}$ variation, radiopacity, solubility, dimensional changes, flow and release of chemical elements. Data were analyzed statistically by ANOVA and Tukey's test $(\square=0.05)$. Longer setting time and higher dimensional changes and solubility values were exhibited by 1:0.65 and 1:0.5 ratios $(p<0.05)$. The 1:0.5 and $1: 0.65$ ratios exhibited the highest $\mathrm{pH}$ values at all time points. All materials exhibited high radiopacity values. Significant differences were found only between 1:0.5 and 1:1 ratios for calcium and zinc release $(p<0.05)$, whereas the amount of zirconium was similar among all groups $(p>0.05)$. Considering the evaluated proprieties, combinations of Calen ${ }^{\circledast}$ paste with ZO at 1:0.5 and 1:0.65 ratios had the best results as root canal filling materials for use in primary teeth.
\end{abstract}

Key Words: filling materials, primary teeth, calcium hydroxide, $\mathrm{pH}$, radiopacity, setting time, dimensional changes, solubility.

\section{Introduction}

Root canal filling materials used in primary teeth must have compatibility with the apical and periapical tissues, stimulating or enabling repair by means of the deposition of mineralized cementoid tissue or fibrous connective tissue; be easily placed in and removed from the canals, if necessary; exhibit antimicrobial activity; be radiopaque; adhere to the canal walls without suffering shrinkage; not be soluble in water; not cause tooth discoloration; not set as a compact mass that could interfere with the eruption of permanent successor teeth; be phagocytized together with the physiological resorption of deciduous tooth roots, as well as when they spill accidentally (1). Although several materials have been proposed, no single material used in primary teeth fulfills all requirements of an ideal root filling material (2).

Among the filling materials used for primary teeth, one of then frequently used are materials based on zinc oxide and eugenol $(2,3)$. They can trigger chronic inflammatory reactions in the periapical tissues $(3,4)$, they alter various cell functions like viability (5), proliferation, and adhesion (6) of cells; they induce the expression of pro-inflammatory cytokines (7); they alter the process of phagocytosis (8); they alter the function of neutrophils (9); they act as inhibitors of cell respiration (10). In addition, these materials are poorly phagocytosed and eliminated despite the physiological resorption of roots (11). Finally, zinc oxide and eugenol (ZOE) can alter the permanent tooth eruption path (12), and they exhibit high apical marginal infiltration (13).

Another group of filling materials for root canals in primary teeth is calcium hydroxide-based materials $(14,15)$.
Despite their excellent biological properties $(14,16)$, calcium hydroxide-based pastes do not exhibit physical properties adequate for clinical use because they are permeable to tissue fluids and soluble within the root canal. In addition, these pastes exhibit poor flow, viscosity, and adherence, and they are radiolucent.

Several authors have suggested thickening calcium hydroxide-based pastes with zinc oxide to allow for their use as filling materials of root canals in primary teeth (15), thus reducing their phagocytosis, the speed of which, from a clinical perspective, must be the same as that of deciduous tooth root resorption, and improving their physical and chemical properties, resulting in working consistency and radiopacity (15). In addition, the zinc oxide-thickened Calen ${ }^{\oplus}$ paste exhibited in vivo biocompatibility (14), high antimicrobial activity (17), and satisfactory clinical and radiographic outcomes (18). Nevertheless, studies are needed to establish the ideal paste-to-zinc oxide ratio for Calen paste clinical use without impairment of its ionic dissociation, $\mathrm{pH}$, conductivity, while maintaining good radiopacity and low solubility and undergoing dimensional changes.

For the above-mentioned reasons, no currently available filling material for deciduous tooth root canals exhibits all of the ideal physical, chemical, antimicrobial, and biological requirements, whereas the use of a filling material complying with all of these requirements would be of paramount importance to increasing the success level of post-endodontic treatment in primary teeth.

It would be helpful to known, on the basis of physical and chemical properties of the materials, which would the 
best concentration of zinc oxide and calcium hydroxide for the endodontic treatment of primary teeth be effective and successful. Therefore the aim of the present study was to assess in vitro the $\mathrm{pH}$, radiopacity, release of chemical elements, setting time, dimensional changes, solubility, flow, and root dentin penetrability of a calcium hydroxide-based paste (Calen ${ }^{\oplus}$ ) mixed with various proportions of zinc oxide $(1: 0.5 ; 1: 0.65 ; 1: 0.8 ; 1: 1)$ compared with zinc oxide-eugenol (ZOE) cement and to a calcium hydroxide-based endodontic cement (Sealapex ${ }^{\circledast}$ ).

\section{Material and Methods}

\section{Materials}

The following materials were used in the present study: a calcium hydroxide-based paste (Calen ${ }^{\circledR}$ ) combined with various proportions $(1: 0.5 ; 1: 0.65 ; 1: 0.8 ; 1: 1)$ of zinc oxide (ZO); a zinc oxide and eugenol cement (ZOE); and a calcium hydroxide-based endodontic cement (Sealapex ${ }^{\circledR}$ ).

All of the tests that were performed complied with American National Standards Institute/American Dental Association - ANSI/ADA 57-2000 specification for endodontic sealing materials, which establishes that they must be performed at a room temperature of $23 \pm 2{ }^{\circ} \mathrm{C}$. The manipulation of cements was performed according to their manufacturers' specifications.

To thicken Calen ${ }^{\oplus}$ paste with zinc oxide, the paste was removed from its original packaging, weighed, and placed on a glass plate, where it was mixed with zinc oxide, also previously weighed, in the various analyzed proportions.

\section{Setting Time}

Cylindrical plastic molds, measuring $10 \mathrm{~mm}$ in internal diameter and $2 \mathrm{~mm}$ in thickness, were built, fixated in a plastic container using utility wax, and filled with the cements and pastes to be tested. The container was kept at constant temperature of $37{ }^{\circ} \mathrm{C}$ in a stove (Odontobras ECB 1.3 Digital, São Paulo, SP, Brazil) in 95\% relative humidity. At $150 \pm 10 \mathrm{~s}$ after the mixture onset, a $100 \mathrm{~g}$ Gillmore-type needle with an active tip $2.5 \mathrm{~mm}$ in diameter was vertically placed on the horizontal surface of the material repeatedly at 60 -s intervals until the formation of indentations decreased or was eliminated. The setting time of the materials was defined as the time elapsed from mixture onset until the moment of maximal reduction (and not elimination) of the indentations because the pastes did not set.

\section{$\mathrm{pH}$ values}

The tested materials were manipulated and placed inside transparent polyethylene tubes measuring $1 \mathrm{~mm}$ in internal diameter and $10 \mathrm{~mm}$ in length with one open end $(n=5$ per material). After a waiting period of approximately 30 $\min$, the tubes were separately placed in beakers containing $10 \mathrm{~mL}$ of deionized water.

After the resting period, the $\mathrm{pH}$ was directly measured inside the beakers. For that purpose, a glass electrode coupled to a digital pH meter (Model DM-20 Digimed; Digicrom Analítica Ltda, São Paulo, SP, Brazil), previously calibrated with pH 6.86 and 4.0 buffer solutions (Digimed; Digicrom Analítica Ltda), was immersed in the beaker solution. The electrode was abundantly rinsed with distilled water between readings and thoroughly dried with absorbent paper. Whenever the electrode was not in use, it remained in contact with the buffer solution, which was renewed after each measurement.

The $\mathrm{pH}$ values at $30 \mathrm{~min}$ and at $2,5,75,298,342$, and $513 \mathrm{~h}$ were duly recorded.

Statistical analysis was performed by calculating the mean value exhibited by the samples at each investigated time point for each material.

\section{Radiopacity}

To perform this test, acrylic plates (1-mm-thick, 2.2-cmwide, and $4.5-\mathrm{cm}$-long) were built, each including four perforations of $5 \mathrm{~mm}$ in internal diameter. Each perforation was filled with one of the tested materials and was covered by a glass plate wrapped with cellophane film. The full set was pressed to cause the excess cement to spill; therefore, a sample $1 \mathrm{~mm}$ thick and $5 \mathrm{~mm}$ in diameter was obtained for each material ( $n=4$ per material).

The cements were added to the test specimens according to the order of the material setting times, i.e., from the longest to the shortest. Thus, the samples became simultaneously ready for radiographic assessment after a period equal to three times the setting time of the materials, during which they were stored in a stove at $37^{\circ} \mathrm{C}$ and $95 \%$ relative humidity.

Each acrylic plated filled with cement was placed before the radiographic sensor at a focus-object distance of $30 \mathrm{~cm}$. Next to each plate, a 99\% aluminum (1100 alloy) stair with a thickness varying from 1 to $10 \mathrm{~mm}$ and 1-mm uniform steps was placed, which allowed for the comparison of the aluminum stairs and the respective samples on the same radiograph.

Next, radiographic images of the material samples and stairs were acquired using occlusal film (Insight 10-41; Kodak Company, Rochester, NY, USA) and a Weber X-ray device (Weber Dental Manufacturing Co., Canton, OH, USA) at the School of Dentistry of Ribeirão Preto at the University of São Paulo with a focus-film distance of $1 \mathrm{~m}$, adjusted for $60 \mathrm{kVp}$ and $10 \mathrm{~mA}$ of exposure, for $0.6 \mathrm{~s}$. Processing involved $2 \mathrm{~min}$ in the developing solution $\left(27^{\circ} \mathrm{C}\right), 30 \mathrm{~s}$ in the intermediate rinse solution, $4 \mathrm{~min}$ in the fixer solution, and $10 \mathrm{~min}$ in the final rinse solution. 
Once obtained, the radiographs were placed on a professional negatoscope and were digitized using a digital camera (Canon EOS Digital Rebel Xti, Canon Inc., Tokyo, Japan), $3088 \times 2592$ pixels, 0.6 seconds of exposure, ISO 100 diaphragm 16, Canon ES-MACRO, $100 \mathrm{~mm}$ lens). The images were stored in JPEG format.

To analyze the radiographic images, the hue intensity scale of the luminosity channel of the histogram function in Adobe Photoshop (Adobe Systems Incorporated, San Jose, CA, USA) software, version 7.0.1, was used. The histogram's horizontal axis represented the intensity values or levels, ranging from the darkest (zero) on the left end to the lightest (255) on the right end. The vertical axis represented the number of pixels. Thus, a graph of the image's hue scale and registration was obtained such that the details in the low-registration images were concentrated in the radiolucent areas, and the details in the high-registration images were concentrated in the more radiopaque areas.

\section{Solubility}

To perform this test, cylindrical transparent polyethylene tubes were made. The dimensions of this tube were $1 \mathrm{~mm}$ internal diameter and $10 \mathrm{~mm}$ in length with a closed side. The empty tubes were weighed individually with the aid of a precision scale, the values were recorded in a spreadsheet developed especially for this purpose. After weighing the tubes were filled with materials filled primary teeth with the aid of a disposable syringe to avoid the presence of bubbles within the tube. At the end of completion of all the tubes, they were again weighed and the values measured.

The tubes containing the materials were placed in individual wells in a 96 wells culture plate with the open side facing the bottom of the well. With a pipette were added $200 \mu \mathrm{L}$ of distilled and deionized water in each well and the assembly (tube and plate) at a constant temperature of $37{ }^{\circ} \mathrm{C}$ was maintained in the greenhouse (Odontobrás ECB 1.3 Digital - São Paulo, SP, Brazil) with moisture on $95 \%$ for 60 days.

To check the solubility of the material to 1 day before the weighing cell culture plate was removed from the oven and placed in a dehumidifier containing sulfuric acid, to remove all moisture present in the material. Each weighing values were recorded and at the end expressed in percentage of loss. Weights over 60 days were recorded, the weighing being done weekly.

The material loss calculation formula was used: Percentage weight loss = Filled tube - Weight of the empty tube.

\section{Dimensional Changes}

Cylindrical clear polyethylene tubes $(1 \mathrm{~mm}$ internal diameter $\times 10 \mathrm{~mm}$ long) with a closed end were filled with root filling materials for primary teeth using a disposable syringe to avoid bubble formation. The tubes containing the materials were placed in individual wells in a 96-well culture plate with the open side facing the bottom of the well. Using a pipette, $200 \mu \mathrm{L}$ of distilled, deionized water were added in each well and tube/plate set were stored at $37{ }^{\circ} \mathrm{C}$ with $95 \%$ humidity for 30 days. After this period, the sets were removed from the oven and taken to a dehumidifier to remove any moisture present in the material. The initial length of the material was similar to the initial length of the tube $(10 \mathrm{~mm})$ and the final initial length of the material was measured using a digital caliper. The dimensional changes of the material was calculated using the following formula:

$$
\text { Dimensional Changes }=\frac{\mathrm{C}^{30}-\mathrm{C} \times 100}{\mathrm{C}}
$$

Where $\mathrm{C}=$ initial length of the material and $\mathrm{C}^{30}=$ Length of material after 30 days

\section{Flow}

This test was performed following IS0 standard 6876, cited by Asgary (24). After manipulation, $0.5 \mathrm{~mL}$ of the materials was placed at the center of a glass plate using a disposable syringe. After $3 \mathrm{~min}$, as counted from the beginning of manipulation, another glass plate $(20 \mathrm{~g})$ was placed on top of the first plate directly over the cement. A 100-g weight was placed over the set; thus, the total weight over the mass of tested material was $120 \mathrm{~g}$. The set remained stable for $7 \mathrm{~min}$, after which the largest and smallest diameters of each specimen were measured using digital calipers.

\section{Chemical Analysis by Energy-Dispersive X-ray Spectrophotometry (EDX)}

To perform EDX testing, 12 brass tubes ( $n=3$ per material) with $10 \mathrm{~mm}$ of internal diameter and one closed end were used. A total of $200 \mathrm{mg}$ of the tested materials was placed in each tube (Calen ${ }^{\oplus}$ ZO at 0.5:1, 0.65:1, 0.8:1, and 1:1 ratios) as described above and was manipulated similarly to the above-mentioned methods.

The samples were analyzed by means of EDX using XL 30 TMP equipment (Philips, The Netherlands) operating at a high vacuum with $25 \mathrm{~nm}$ of resolution, $0.4 \mathrm{pA}$ to $4 \mu \mathrm{A}$ of current, secondary and backscattered electron detectors, and image magnification of up to $\times 400,000$.

In the present study, quantitative chemical analysis of the samples allowed for the measurement of the chemical elements calcium, zinc, and zirconium.

To perform this test, the samples were first dried using an evaporator and later were placed in a specific device 
on conductive carbon strips and covered with gold. Next, the set was placed in the microscope, which was coupled to a computer equipped with Link ISIS (Halcrow Group Ltd., Tampa, FL, USA) software, to collect and analyze the numerical data obtained. In addition, sample topographic images were recorded ( $\times 100$ magnification) and stored in TIFF (Tagged Image File Format) format.

Statistical analysis of the numerical data was performed by means of the Kruskal-Wallis test using SAS (Statistical Analysis System, SAS Institute Inc., Cary, NC, USA) software at a $5 \%$ level of significance.

\section{Statistical Analysis}

Statistical analysis was performed using Graph Pad Prism software version 4 (Graph Pad Software Inc., San Diego, CA, USA) at a 5\% significance level. The data obtained were subjected to analysis of variance (ANOVA). Differences regarding the flow analyses, setting time, solubility, dimensional changes, radiopacity were submitted to Tukey's post-test. Also, statistical analysis of the numerical data regarding the EDX analyses were performed by KruskalWallis test using SAS (Statistical Analysis System, SAS Institute Inc., Cary, NC, USA) software at a 5\% level of significance.

\section{Results}

\section{Setting Time}

The combination of Calen ${ }^{\oplus}$ paste $+Z 0$ at 1:0.8 ratio and Sealapex ${ }^{\circledast}$ cement exhibited intermediate setting time values, although the time was faster compared with the combinations of Calen ${ }^{\oplus}$ paste + ZO in 1:0.65 and 1:0.5 ratios, which exhibited incomplete and slower setting, compared with the other groups.

\section{pH Analysis}

The graphic representation of $\mathrm{pH}$ analysis at time points of $30 \mathrm{~min}$ and $2,5,75,298,342$, and $513 \mathrm{~h}$ is shown in Figure 1.

With regard to Sealapex ${ }^{\circledast}$, the mean initial pH was 6.1, and it exhibited a progressive increase until reaching a peak at the five-hour time point with mean $\mathrm{pH}$ value of 8.4 followed by a progressive decrease until the last assessed time point (mean $\mathrm{pH}$ value of 5.9).

The mean initial $\mathrm{pH}$ of the ZOE samples was 5.7 followed by a progressive increase until the two hour time point with mean value of 7.5 and subsequent reduction until the values were close to the initial ones (mean of 5.2).

The samples of Calen ${ }^{\oplus}$ paste thickened with ZO in the 1:0.5 and 1:0.65 proportions exhibited similar behavior with regard to $\mathrm{pH}$ along the experimental time points. In both groups, the mean initial pH was 5.7, and the maximal values were achieved at the two-hour time point. It is worth noting that these values (10.9 and 11.7, respectively) were the highest among all of the tested materials. Additionally, the reduction of the mean values until the last assessed time point was the lowest among all of the analyzed materials (mean values of 6.4 and 6.2, respectively).

When Calen ${ }^{\oplus}$ paste was thickened with Z0 in a 1:0.8 proportion, the mean initial pH was 5.7, which increased until reaching its peak at the five-hour time point with a mean value of 9.3 followed by reduction until a final mean value of 5.6 at the 513-hour time point.

Finally, Calen ${ }^{\circledast}$ paste thickened with $Z 0$ in a 1:1 proportion exhibited a mean initial $\mathrm{pH}$ of 5.7, which increased progressively only for the first $30 \mathrm{~min}$ when it reached a maximal mean value of 8.7 ; the mean final $\mathrm{pH}$ value was 6.5 .

It is worth noting that the samples of Sealapex ${ }^{\circledast}$ and ZOE exhibited the lowest peak $\mathrm{pH}$ values among all of the investigated materials, whereas Calen ${ }^{\oplus}$ paste thickened with $Z 0$ in 1:0.5 and 1:0.65 proportions exhibited the highest $\mathrm{pH}$ values at all of the assessed time points.

\section{Radiopacity}

The data indicate that all of the assessed materials exhibited high registration levels, which indicate high radiopacity.

Statistical comparison of the data by ANOVA did not find significant differences ( $p>0.05$ ) among any of the analyzed materials, indicating that they exhibited similar radiopacity.

\section{Solubility}

Sealapex $x^{\oplus}$ showed a lower solubility compared with the other groups $(p<0.0001)$. Calen ${ }^{\circledast}$ paste $+Z 0$ at $1: 0.8$ and 1:1 ratios showed higher solubility compared with Sealapex ${ }^{\circledast}$, which obtained the best value of solubility group. Finally, Calen ${ }^{\oplus}$ paste $+Z 0$ at 1:0.5 and 1:0.65 ratios and ZOE had the highest solubility values, proving highly soluble in water.

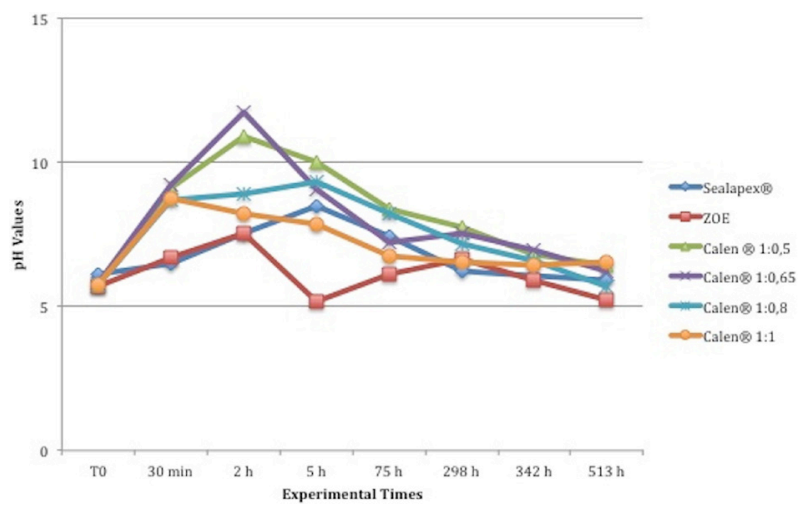

Figure 1. Graphic presentation of the mean $\mathrm{pH}$ values over time for the different root canal filling materials for primary teeth. 


\section{Dimensional Changes}

The Group 6 (Sealapex ${ }^{\oplus}$ ) showed a lower dimensional change compared with the other groups $(p<0.0001)$. The Groups 3,4 and 5 concentrations of $1: 0.8,1: 1$ and zinc oxide and eugenol, respectively, showed a higher dimensional change when compared with Group 6. Groups 1 and 2 at concentrations of $1: 0.5$ and 1:0.65, respectively, achieved the highest values of dimensional change, compared with the other groups.

\section{Flow}

The combination of Calen ${ }^{\oplus}$ paste $+Z 0$ in a 1:1 proportion did not exhibit any flow. Sealapex ${ }^{\oplus}$ cement exhibited the greatest flow with a significant difference compared with the remainder of the groups $(p<0.0001)$ followed by the combinations of Calen ${ }^{\circledast}$ paste $+Z 0$ in 1:0.5 and 1.065 proportions. The combination of Calen ${ }^{\oplus}$ paste $+Z 0$ in a 1:0.8 proportion and ZOE exhibited similar and intermediate values of dimensional changes.

\section{Energy-Dispersive $X$-ray Spectrophotometry (EDX)}

Chemical analysis of the samples of Calen ${ }^{\circledast}$ paste combined with various proportions of ZO (1:0.5; 1:0.65; $1: 0.8 ; 1: 1)$ by means of EDX allowed for the measurement of the initial release, i.e., immediately following the manipulation of the materials, of calcium, zinc, and zirconium, which are chemical elements abundantly present in the assessed materials.

The data described in the table above showed that the release of calcium decreased gradually in direct correlation with the increase in the amount of ZO added to Calen ${ }^{\oplus}$ paste. Statistical analysis by means of the Kruskal-Wallis test $(\alpha=5 \%)$ found a significant difference in the release of calcium only between the 1:0.5 and 1:1 proportions $(p<0.05)$, whereas the release of that chemical element was statistically similar $(p>0.05)$ among the remainder of the Calen ${ }^{\oplus}$ paste-to-ZO proportions.

Contrary to that of calcium, the release of zinc increased gradually with the increase of the proportion of ZO added to Calen ${ }^{\circledast}$ paste. The statistical analysis found a significant difference only between 1:0.5 and 1:1 proportions $(p<0.05)$.

With regard to the release of zirconium, EDX analysis showed a small increase as a function of the amount of ZO added to Calen ${ }^{\oplus}$ paste. However, the statistical analysis did not find significant differences among any of the assessed materials ( $p>0.05$ ).

All these results are provided in Table 1.

\section{Discussion}

Thickening Calen ${ }^{\circledast}$ paste with ZO has been suggested to enable the paste's use as a filling material for root canals in primary teeth $(15,18)$ by reducing its phagocytosis, the speed of which, from a clinical perspective, must be the same as the that of deciduous tooth root resorption, and by improving its physical and chemical properties, such as better working consistency and radiopacity (15), resorption of material synchronously with the physiological root resorption (19), and in vivo biocompatibility (14).

The main goal of thickening Calen ${ }^{\circledast}$ paste with ZO (15) is to improve certain of its physical and chemical characteristics, such as adequate working consistency, material solubilization at a speed concomitant with deciduous tooth rhizolysis, and radiopacity $(15,20)$. In addition, Z0-thickened Calen ${ }^{\circledast}$ paste exhibits high antibacterial activity and satisfactory clinical and radiographic outcomes (18).

Nevertheless, there have been no studies in the literature that have established the ideal paste-to-ZO ratio for clinical use without impairment of the paste's ionic dissociation, $\mathrm{pH}$ and conductivity, while providing satisfactory radiopacity and low solubility and dimensional changes. In the present study, we assessed pH, radiopacity, and release of chemical elements.

In the present study, Sealapex ${ }^{\circledR}$ exhibited low solubility and few dimensional changes, perhaps because methacrylate is the base of its chemical composition. However, these results do not agree with the findings of previous studies, which observed a high degree of solubility and disintegration for that cement (21).

Upon comparison of the solubility of ZO and calcium hydroxide-based cements, according to Driscoll (22), these materials exhibited antagonistic behavior when stored in saline solution or in dentinal fluid. The presence of highly soluble salts could increase the solubility and disintegration of endodontic cements, which could justify the high degree of solubility exhibited in the current study by the combinations of Calen ${ }^{\oplus}$ paste and ZO in 1:0.5 and 1:0.65 proportions and by ZOE.

With regard to the degree of hardening, the combination of Calen ${ }^{\oplus}$ paste and ZO in a 1:1 proportion exhibited the

Table 1. Mean values and standard deviation of calcium, zinc and zirconium release from the samples of Calen ${ }^{\circledR}$ paste thickened with various proportions of zinc oxide

\begin{tabular}{lccc}
\hline & Calcium & Zinc & Zirconium \\
\hline $\begin{array}{l}\text { Calen }{ }^{\circledR}+\text { ZO } \\
1: 0.5\end{array}$ & $46.14(4.22)^{*}$ & $51.95(3.86)^{*}$ & $1.86(0.34)$ \\
$\begin{array}{l}\text { Calen }{ }^{\circledR}+\text { ZO } \\
1: 0.65\end{array}$ & $43.14(2.51)$ & $55.85(0.05)$ & $1.59(0.47)$ \\
$\begin{array}{l}\text { Calen }{ }^{\circledR}+\text { ZO } \\
1: 0.8\end{array}$ & $40.89(0.69)$ & $56.77(1.39)$ & $2.32(0.70)$ \\
$\begin{array}{l}\text { Calen } \\
1: 1\end{array}$ & $36.96(2.96)^{*}$ & $60.77(3.26)^{*}$ & $2.24(0.29)$ \\
\hline
\end{tabular}

*Without statistically significant difference ( $p>0.05)$. 
most complete and most rapid hardening, as a function of the amount of ZO added to thicken the Calen ${ }^{\oplus}$ paste. Sealapex ${ }^{\circledast}$ cement exhibited intermediate values.

A study conducted in 2006, to assess the degree of flow of some endodontic cements, found that Sealapex ${ }^{\circledR}$ exhibited a satisfactory degree of flow (23), which agrees with our study, in which this material exhibited the highest level of flow among all of the analyzed materials.

A study that compared the effectiveness of ZOE and thickened Calen ${ }^{\oplus}$ paste found that both materials achieved clinical and radiographic success; thus, both might be similarly adequate as filling materials for primary teeth (18).

The physicochemical tests performed in the present study suggest that Sealape ${ }^{\oplus}$ and the combinations of Calen ${ }^{\oplus}$ paste and $Z O$ in 1:0.5 and 1:0.65 proportions are the best-indicated filling materials for root canals in primary teeth. Nevertheless, future in vivo studies are needed to assess other properties of such materials, such as the progression of physiological root resorption of primary teeth relative to the resorption of filling materials for root canals.

\section{Resumo}

0 objetivo do presente estudo foi avaliar propriedades físico-químicas da pasta à base de hidróxido de cálcio (Calen ${ }^{\circledast}$ ) combinado com diferentes proporções de óxido de zinco (OZ) (1:0,5 e 1:0,65, 1:0,8 e 1:1) (Calen ${ }^{\oplus}$ $\mathrm{OZ})$. Os materiais foram comparados quanto ao tempo de endurecimento, variação do $\mathrm{pH}$, radiopacidade, solubilidade, alterações dimensionais, escoamento e liberação de elementos químicos. Os dados obtidos foram submetidos à análise de variância (nível de 5\% de significância). Maior grau de endurecimento, valores de alterações dimensionais, e solubilidade foram encontrados para Calen ${ }^{\oplus} / 0 Z$ 1:0,65 e 1:0,5. Calen ${ }^{\oplus} / 0 Z$ 1:0,5 e 1:0,65, apresentaram os maiores valores de $\mathrm{pH}$ em todos os momentos. Todos os materiais apresentaram valores elevados de radiopacidade com diferenças significativas ( $>$.05). Foram encontradas diferenças significativas apenas entre Calen ${ }^{\circledast} / 0 Z$ de 1:0,5 e 1:1 na liberação de cálcio e zinco $(p<0,05)$, enquanto que a quantidade de zircônia foi semelhante entre todos os grupos analisados ( $p>05)$. Em relação às propriedades avaliadas no presente estudo, as combinações de Calen ${ }^{\circledR}$ com óxido de zinco nas proporções 1:0,5 e 1:0,65 são mais adequadas como material obturador para os canais radiculares de dentes decíduos.

\section{Acknowledgements}

The authors received financial support from The São Paulo State Research Foundation (FAPESP - grant 2011/00277-7).

\section{References}

1. Gupta S, Das G. Clinical and radiographic evaluation of zinc oxide eugenol and metapex in root canal treatment of primary teeth. J Indian Soc Pedod Prev Dent 2011;29:222-228.

2. Ramar K, Mungara J. Clinical and radiographic evaluation of pulpectomies using three root canal filling materials: an in-vivo study. J Indian Soc Pedod Prev Dent 2010;28:25-29.

3. Silva LA, Leonardo MR, Oliveira DS, Silva RA, Queiroz AM, Hernández $P G$, Nelson-Filho P. Histopathological evaluation of root canal filling materials for primary teeth. Braz Dent J 2010;21:38-45.

4. Yesilsoy C, Koren LZ, Morse DR, Kobayashi C. A comparative tissue toxicity evaluation of established and newer root canal sealers. Oral Surg Oral Med Oral Pathol 1988;65:459-467.

5. Correa GT, Veranio GA, Silva LE, Hirata Junior R, Coil JM, Scelza MF. Cytotoxicity evaluation of two root canal sealers and a commercial calcium hydroxide paste on THP1 cell line by Trypan Blue assay. J Appl Oral Sci 2009;17:457-461.

6. Willershausen I, Callaway A, Briseño B, Willershausen B. In vitro analysis of the cytotoxicity and the antimicrobial effect of four endodontic sealers. Head Face Med 2011;10:7-15.

7. Haglund $R, H e$ J, Jarvis J, Safavi KE, Spångberg LS, Zhu O. Effects of root-end filling materials on fibroblasts and macrophages in vitro. Oral Surg Oral Med Oral Pathol Oral Radiol Endod 2003;95:739-745.

8. Segura JJ, Jiménez-Rubio A, Guerrero JM, Calvo JR, Feito JJ. Effect in vitro of Tifell (formocresol-eugenol) on macrophage adhesion. Int Endod J 1998;31:112-116.

9. Chen PY, Lin AY, Lin YS, Seki Y, Stokes AG, Peyras J, Olevsky EA, Meyers MA, McKittrick J. Structure and mechanical properties of selected biological materials. J Mech Behav Biomed Mater 2008;1:208-226.

10. Markowitz K, Moynihan M, Liu M, Kim S. Biologic properties of eugenol and zinc oxide-eugenol. A clinically oriented review. Oral Surg Oral Med Oral Pathol 1992;73:729-737.

11. Primosch RE, Ahmad i A, Setzer B, Guelmann M. A retrospective assessment of zinc oxide-eugenol pulpectomies in vital maxillary primary incisors successfully restored with composite resin crowns. Pediatr Dent 2005;27:470-477.

12. Mortazavi M, Mesbahi M. Comparison of zinc oxide and eugenol, and Vitapex for root canal treatment of necrotic primary teeth. Int J Paediatr Dent 2004;14:417-424.

13. Bawazir OA, Salama FS. Clinical evaluation of root canal obturation methods in primary teeth. Pediatr Dent 2006;28:39-47.

14. Queiroz AM, Assed S, Consolaro A, Nelson-Filho P, Leonardo MR, Silva RA, Silva LA. Subcutaneous connective tissue response to primary root canal filling materials. Braz Dent J 2011; 22: 203-211.

15. Queiroz AM, Nelson-Filho P, Silva LA, Assed S, Silva RA, Ito IY. Antibacterial activity of root canal filling materials for primary teeth: zinc oxide and eugenol cement, Calen paste thickened with zinc oxide, Sealapex and EndoREZ. Braz Dent J 2009;20:290-6.

16. da Silva LA, de Freitas AC, de Carvalho FK, de Queiroz AM, Nelson-Filho P, Porto-Neto ST. Direct pulp capping with a self-etching adhesive system: histopathologic evaluation in dogs' teeth. Oral Surg Oral Med Oral Pathol Oral Radiol Endod 2009;108:e34-40.

17. Maekawa LE, Valera MC, Oliveira LD, Carvalho CA, Koga-Ito CY, Jorge AO. In vitro evaluation of the action of irrigating solutions associated with intracanal medications on Escherichia coli and its endotoxin in root canals. J Appl Oral Sci 2011;19:106-112.

18. Pinto DN, de Sousa DL, Araújo RB, Moreira-Neto JJ. Eighteen-month clinical and radiographic evaluation of two root canal-filling materials in primary teeth with pulp necrosis secondary to trauma. Dent Traumatol 2011;27:221-224.

19. Chawla HS, Mathur VP, Gauba K, Goyal A. A mixture of $\mathrm{Ca}(\mathrm{OH}) 2$ paste and $\mathrm{ZnO}$ powder as a root canal filling material for primary teeth: a preliminary study. J Indian Soc Pedod Prev Dent 2001;19:107-109.

20. Tanomaru-Filho M, Jorge EG, Guerreiro Tanomaru JM, Gonçalves M. Radiopacity evaluation of new root canal filling materials by digitalization of images. J Endod 2007;33:249-251.

21. Schäfer $E$, Zandbiglari T. Solubility of root-canal sealers in water and artificial saliva. Int Endod J. 2003;36:660-669.

22. Driscoll CF, Woolsey GD, Reddy TG, Craig RG. Solubility of oxideeugenol and calcium hydroxide cements in simulated dentinal fluid. J Rehabil 1989;16:45I-455.

23. Valera $\mathrm{MC}$, Camargo $\mathrm{CH}$, Carvalho $\mathrm{AS}$, Gama ER. In vitro evaluation of apical microleakage using different root-end filling materials. J Appl Oral Sci 2006;14:49-52. 